\title{
MINAT MENGEMBANGKAN USAHA BAGI PENERIMA PROGRAM MAHASISWA WIRAUSAHA FAKULTAS PARIWISATA DAN PERHOTELAN UNIVERSITAS NEGERI PADANG
}

\author{
Destoni Candra \\ Program Studi D4 Manajemen Perhotelan \\ Jurusan Pariwisata \\ Fakultas Pariwisata dan Perhotelan Universitas Negeri Padang \\ E-mail: candradestoni@yahoo.co.id
}

\begin{abstract}
Abstrak. Penelitian ini bertujuan untuk mengetahui minat Mengembangkan Usaha Bagi Penerima Program Mahasiswa Wirausaha Fakultas Pariwisata dan Perhotelan Universitas Negeri Padang ditinjau dari faktor internal dan faktor eksternal. Penelitian yang dilakukan merupakan penelitian kuantitatif dengan data primer dan sekunder. Populasi penelitian ini adalah mahasiswa penerima Program Mahasiswa Wirausaha Fakultas Pariwisata dan Perhotelan Universitas Negeri Padang Tahun 2016 dan 2017. Sampel dari penelitian ini berjumlah 67 orang. Teknik pengumpulan data dilakukan dengan menggunakan kuesioner (angket) dengan skala Likert yang telah teruji validitas dan reliabilitasnya. Teknik analisis data dimulai dari verifikasi data dan menghitung nilai jawaban responden pada tingkat capaian responden (TCR). Hasil penelitian menemukan minat berwirausaha mahasiswa Fakultas Pariwisata dan Perhotelan Universitas Negeri Padang dilihat dari segi faktor internal termasuk kategori baik dengan skor ratarata sebesar 3,81 dengan total capaian responden (TCR) sebesar 76,2\%, faktor eksternal termasuk dalam kategori baik dengan skor rata-rata sebesar 3,72 dengan TCR sebesar 77,23\%.
\end{abstract}

Kata Kunci: Minat, Berwirausaha, Mahasiswa.

\section{PENDAHULUAN}

Minat wirausaha adalah keinginan, ketertarikan dan kesediaan bekerja keras atau berkemauan keras untuk berusaha memenuhi kebutuhan hidupnya dan menciptakan usaha baru tanpa merasa takut dengan resiko yang akan terjadi serta senantiasa belajar dari kegagalan dalam berwirausaha, (Mochamad, 2013). Hal yang sama juga dikemukakan oleh Fuadi dalam Rano (2012) bahwa minat berwirausaha adalah keinginan, ketertarikan serta kesediaan untuk berusaha secara maksimal untuk memenuhi kebutuhan hidupnya tanpa merasa takut dengan resiko yang akan terjadi, serta berkemauan keras untuk belajar dari kegagalan.
Wibowo dalam Octavionica

(2016)

menyatakan bahwa faktor-faktor yang mempengaruhi minat berwirausaha dapat dikelompokkan menjadi faktor internal dan faktor eksternal. Faktor internal terdiri dari perasaan senang, kemampuan dan motif berprestasi. Sedangkan faktor eksternal terdiri dari faktor lingkungan dan faktor keluarga.

Berdasarkan observasi dan wawancara penulis pada 21 November 2017, berbagai masalah terjadi pada peserta Penerima Program Mahasiswa Wirausaha Fakultas Pariwisata dan Perhotelan Universitas Negeri Padang yaitu minat untuk mengembangkan PMW mahasiswa FPP UNP masih rendah sehingga banyak yang hanya menjalani program tersebut hanya satu tahun saja, banyak dari mereka mengatakan 
bahwa motivasi mereka mengajukan program yang mereka usulkan itu hanya sebagai syarat kelulusan mata kuliah kewirausahaan yang mereka ambil. Banyak dari mereka yang kurang senang menjalani PMW, kemampuan mereka pun masih kurang pada usaha yang mereka jalani, banyak dari mereka yang mengeluh mengenai pendanaan yang tidak sesuai dengan pengajuan, pengelolaannya tidak maksimal karena terganggu kegiatan perkuliahan, keluarga mereka menuntut mereka bekerja setelah wisuda nanti dan kurang mendukung untuk berwirausaha.

Tujuan penelitian ini adalah untuk mengetahui minat Mengembangkan Usaha Bagi Penerima Program Mahasiswa Wirausaha Fakultas Pariwisata dan Perhotelan Universitas Negeri Padang dengan faktor internal dan faktor eksternal.

\section{METODE PENELITIAN}

Jenis penelitian yang dilakukan digolongkan kepada penelitan kuantitatif dengan variabel minat berwirausaha faktor internal dan faktor eksternal. Populasi penelitian ini adalah Mahasiswa Penerima Program Mahasiswa Wirausaha Fakultas Pariwisata dan Perhotelan Universitas Negeri Padang tahun 2016 dan 2017. Sedangkan sampel dari penelitian ini berjumlah 67 orang. Jenis data penelitian ini adalah data primer dan sekunder dengan teknik pengumpulan data kuesioner. Teknik analisis data dimulai dari verifikasi data dan menghitung nilai jawaban responden pada tingkat capaian responden (TCR).

HASIL PENELITIAN DAN PEMBAHASAN

1. Hasil Penelitian

a. Karakteristik Responden
Responden yang diambil dalam penelitian ini adalah para mahasiswa penerima program PMW Fakultas Pariwisata dan Perhotelan Universitas Negeri Padang sebanyak 67 orang.

1) Karakteristik Responden Berdasarkan Jenis Kelamin

Berdasarkan pengelompokkan jenis kelamin diketahui bahwa $44,8 \%$ responden adalah laki-laki dan 55,2\% responden adalah perempuan. Dalam hal ini dapat disimpulkan bahwa pada umumnya responden pada penelitian ini adalah berjenis kelamin perempuan.

2) Karakteristik Responden Berdasarkan Program Studi

Berdasarkan pengelompokkan program studi diketahui bahwa responden dari program studi Pendidikan Kesejahteraan Keluarga sebanyak 10 orang atau 14,93\%, responden dari program studi Manajemen Perhotelan sebanyak 23 orang atau 34,33\%, responden dari program studi Pendidikan Tata Rias Kecantikan sebanyak 6 orang atau sekitar $8,96 \%$, responden dari program studi Tata Boga sebanyak 19 orang atau sekitar 28,36\% serta responden yang berasal dari program studi Tata Busana sebanyak 9 orang atau sekitar $13,43 \%$. Hal ini menunjukkan bahwa mayoritas para responden berasal dari program studi Manajemen Perhotelan sebanyak 23 orang atau sekitar 34,44\%.

\section{b. Deskriptif Variabel Penelitian}

Variabel penelitian ini adalah minat berwirausaha dengan sub variabel faktor internal dan faktor eksternal. Adapun indikator dari faktor internal adalah perasaan dan ketertarikan, motif berprestasi dan kemampuan dalam berwirausaha. Sedangkan indikator dari faktor eksternal adalah pengaruh lingkungan dan dorongan dari keluarga. 
Berikut ini adalah deskripsi masingmasing variabel penelitian, berdasarkan nilai total capaian jawaban responden (TCR).

1) Faktor internal minat berwirausaha

Has 1 analisis deskriptif data tentang variabel faktor internal minat berwirausaha mahasiswa Fakultas Pariwisata dan Perhotelan Universitas Negeri Padang adalah dengan skor rata-rata sebesar 3,81 dengan TCR sebesar $76,2 \%$. Hal ini menunjukkan bahwa minat pada mahasiswa penerima program wirausaha Fakultas Pariwisata dan Perhotelan Universitas Negeri Padang dalam berwirausaha termasuk kedalam kategori baik.

Berdasarkan enam belas item yang penulis berikaan kepada responden, item yang paling rendah penilaian responden pada nomor 16, yaitu "Saya bersungguh-sungguh dalam melaksanakan praktik berwirausaha melalui PMW agar kelak ketika saya memiliki usaha dapat menuai kesuksesan". Hal ini berarti mahasiswa penerima program wirausaha Fakultas Pariwisata dan Perhotelan Universitas Negeri Padan masih belum yakin jika mereka bersungguh-sungguh untuk berusaha akan memperole kesuksean dalam kewirausahaan karena ini masih dalam imajinasi mereka.

2) Faktor eksternal minat berwirausaha

Hasil analisis deskriptif data tentang variabel faktor eksternal berwirausaha mahasiswa Fakultas Pariwisatan dan Perhotelan Universitas Negeri Padang adalah skor ratarata sebesar 3,96 dengan total capaian responden (TCR) sebesar 79,24\%. Hal ini menunjukkan bahwa minat pada mahasiswa penerima program wirausaha Fakultas Pariwisata dan Perhotelan Universitas Negeri Padang dalam berwirausaha dilihat dari pengaruh atau faktor eksternal mahasiswa itu sendiri adalah termasuk ke dalam kategori baik.
Berdasarkan 13 item pernyataan yang penulis berikan kepada responden, item yang paling rendah penilaian responden pada item no 12, yaitu "Saya ingin meneruskan usaha orang uta saya sehingga saya banyak belajar dari praktik berwirausaha melalui PMW". Hal ini berarti mahasiswa penerimaprogram wirausaha Fakultas Pariwisata dan Perhotelan Universitas Negeri Padang masih belum yakin jika mereka ingin meneruskan usaha orang tua mereka karena mungkin mahasiswa ini mempunyai keinginan sendiri atau ada usaha yang lebih mereka tekuni selain dari usaha orang tua mereka itu sendiri kedalam kategori baik.

\section{Pembahasan}

\section{a. Minat Mengembangkan Usaha \\ 1) Faktor Internal}

Diketahui bahwa rata-rata skor jawaban yang diperoleh berada dalam kategori baik, hal ini berarti mahasiswa merasakan bahwa faktor internal yang ada dalam diri mereka tersebut sudah baik dalam menumbuhkan minat untuk berwirausaha. Namun dari pernyataan pada variabel faktor internal minat berwirausaha, jawaban terendah responden yaitu "Saya bersungguh-sungguh dalam melaksanakan praktik berwirausaha melalui PMW agar kelak ketika saya memiliki usaha dapat menuai kesuksesan". Hal ini berarti bahwa mahasiswa masih belum terlalu bersungguh-sungguh atas kemampuan mereka dalam berwirausaha.

Pada variabel faktor internal minat berwirausaha dengan indikator perasaan senang dan ketertarikan diketahui bahwa rata-rata skor jawaban yang diperoleh berada dalam kategori baik.

Menurut wibowo dalam Octavionica (2016) perasaan erat hubungannya dengan pribadi seseorang, maka tanggapan perasaan 
seseorang terhadap sesuatu hal tidaklah sama antara orang yang satu dengan orang yang lain. Perasaan senang terhadap bidang wirausaha akan menimbulkan minat berwirausaha.

Pada variabel faktor internal minat berwirausaha dengan indikator motif berprestasi diketahui bahwa ratarata skor jawaban yang diperoleh berada dalam kategori baik. Menurut Mega Widya Kumaladewi dalam Octavionica (2016), kemampuan adalah suatu kecakapan seseorang dalam bidang tertentu yang dapat diperoleh dari hasil belajar, melalui pendidikan formal, informal maupun non formal. Melalui adanya kemampuan dalam berwirausaha tentu akan menimbulkan minat berwirausaha. Pada variabel ini diketahui bahwa rata-rata skor jawaban yang diperoleh berada dalam kategori baik. Menurut Arista Lukmayanti dalam Octavionica (2016), motif berprestasi merupakan keinginan untuk dapat menjadi orang yang lebih baik dari orang lain. Motif berprestasi menjadi motivasi seseorang untuk dapat memperoleh kehidupan yang lebih baik.

\section{2) Faktor Eksternal}

Diketahui bahwa rata-rata skor jawaban diperoleh berada dalam kategori baik, hal ini berarti mahasiswa merasakan bahwa faktor tersebut sudah baik dalam menumbuhkan minat, semangat serta motivasi mereka untuk berwirausaha. Namun dari pernyataan pada variabel faktor eksternal minat berwirausaha, jawaban terendah responden terdapat pada pernyataan "Saya ingin meneruskan usaha orang uta saya sehingga saya banyak belajar dari praktik berwirausaha melalui PMW". Hal ini berarti mahasiswa penerima PMW FPP UNP masih belum yakin untuk meneruskan usaha orang tua mereka karena mungkin mereka memiliki keingan untuk bekerja di perusahaan orang lain atau ada usaha yang lebih menarik untuk mereka tekuni.

Pada variabel faktor eksternal minat berwirausaha dengan indikator pengaruh lingkungan diketahui bahwa rata-rata skor jawaban yang diperoleh berada dalam kategori baik. Menurut Wibowo dalam Octavionica (2016) faktor lingkungan yang mempengaruhi minat berwirausaha seperti lingkungan masyarakat serta nilai-nilai yang tumbuh dalam masyarakat tersebut.

Pada variabel faktor eksternal minat berwirausaha dengan indikator dorongan dari keluarga diketahui bahwa rata-rata skor jawaban yang diperoleh berada dalam kategori baik. Menurut Wibowo dalam Octavionica (2016) adanya dorongan dari orang tua dan keluarga dapat memperngaruhi seseorang dalam memupuk minat berwirausaha.

\section{KESIMPULAN DAN SARAN \\ Kesimpulan}

a. Minat berwirausaha mahasiswa Fakultas Pariwisata dan Perhotelan Universitas Negeri Padang dilihat dari segi faktor internal termasuk dalam kategori baik dengan skor rata-rata 3,81 dan TCR sebesar $76,2 \%$.

b. Minat berwirausaha mahasiswa Fakultas Pariwisata dan Perhotelan Universitas Negeri Padang dilihat dari segi faktor eksternal termasuk dalam kategori baik dengan skor rata-rata sebesar 3,72 dengan TCR sebesar $77,23 \%$

\section{Saran}

Berdasarkan hasil penelitian yang menunjukkan minat berwirausaha mahasiswa kategori baik, maka pengelola PMW seharusnya meningkatkan pengelolaan dan bimbingan ke arah lebih baik agar mahasiswa penerima PMW bisa mengembangkan usahanya 
nanti. Menurut peneliti, pihak Fakultas Pariwisatan dan Perhotelan Universitas Negeri Padang terus mendukung dan memotivasi mahasiswa untuk memiliki minat berwirausaha serta mengembangkan usahanya menjadi lebih menguntungkan. Jika berdasarkan penelitian, maka peserta penerima PMW FPP sebaiknya mengembangkan usahanya karena sangat dibutuhkan oleh orang banyak. Sedangkan saran untuk peneliti selanjutnya adalah meneliti faktor-faktor penghambat PMW FPP Universitas Negeri Padang dan faktor-faktor yang menghambat mahasiswa penerima PMW FPP tidak mengembangkan usahanya.

Catatan: Jurnal ini disusun berdasarkan skripsi penulis dengan pembimbing Waryono, S.Pd, MM.Par

\section{DAFTAR PUSTAKA}

Alfaruk, Muchamad Hasym. 2013. Pengaruh Faktor Personal Terhadap Minat Berwirausaha pada Mahasiswa Pendidikan Ekonomi Universitas Negeri
Surabaya. Jurnal Pendidikan Tata Niaga (JPTN). Vol 1 No 3 1-20.

Arikunto, Suharsimi. 2007. Prosedur Penelitian Suatu Pendekatan Praktik. Jakarta: Rineka Cipta.

Octavionica, Adhe. 2016. Pengaruh Motivasi Berwirausaha serta Lingkungan Internal dan Lingkungan Eksternal Terhadap Minat Berwirausaha Mahasiswa Pendidikan Ekonomi Universitas Lampung. Bandar Lampung: Universitas Lampung.

Putri, Aditia Rano. 2012. Faktor-Faktor yang Mempengaruhi Minat Mahasiswa Manajemen untuk Berwirausaha. Jurnal Manajemen. Vol 1 No 1. 